\title{
ADAPTABILITY AND STABILITY FOR IRON AND ZINC IN COWPEA BY AMMI ANALYSIS ${ }^{1}$
}

\author{
CARLOS ENRIQUE CARDONA-AYALA ${ }^{2 *}$, HERMES ARAMENDIZ-TATIS ${ }^{3}$, MIGUEL MARIANO ESPITIA \\ $\mathrm{CAMACHO}^{3}$
}

\begin{abstract}
Iron and zinc deficiency is one of the main problems affecting vulnerable populations in the Colombian Caribbean, thereby generating malnutrition from the consumption of foods with low content of essential minerals. The objective of this study was to evaluate the genotype-environment interaction for iron and zinc accumulation in grains in 10 cowpea bean genotypes by additive main effects and multiplicative interaction (AMMI) model and to select the most stable ones to stimulate their planting or as parents in the genetic improvement program. Nine promising lines and a commercial control were evaluated using the randomized complete block design with 10 treatments and four replications in 10 environments of the northern Colombia in the second semester of 2017 and first of 2018. The adaptability and stability analysis was done using AMMI model. The results showed highly significant differences at the level of environments, genotypes, and genotype-environment interaction for iron and zinc, demostrating a differential adaptability of genotypes in the test environments. Genotypes 2 and 3 expressed greater adaptability and stability for iron contents in the seed; while genotype 1 , recorded it for zinc contents. These three genotypes outperformed the commercial control and, therefore, can be recommended for planting or be used as parents in the genetic improvement program.
\end{abstract}

Keywords: Vigna unguiculata. Biofortification. Genotype-environment interaction. Micronutrients. Malnutrition.

\section{ADAPTABILIDADE E ESTABILIDADE DE FERRO E ZINCO EM FEIJÃO-CAUPI POR MEIO DA ANÁLISE AMMI}

RESUMO - A deficiência de ferro e zinco é um dos principais problemas que afeta populações vulneráveis do Caribe colombiano, gerando desnutrição pelo consumo de alimentos com baixos conteúdos de minerais essenciais. O objetivo do estudo foi avaliar a interação genótipo x ambiente para acumulação de ferro e zinco nos grãos em 10 genótipos de feijão-caupi por meio do o modelo de efeitos principais aditivos e interação multiplicativa (AMMI) e selecionar os mais estáveis para estimular o plantio ou como parentais no programa de melhoramento genético. Nove linhas promissoras e um controle comercial foram avaliados usando o delineamento em blocos ao acaso com 10 tratamentos e quatro repetições em 10 ambientes do norte da Colômbia no segundo semestre de 2017 e primeiro de 2018. A análise de adaptabilidade e estabilidade foi realizada utilizando o modelo AMMI. Os resultados mostraram diferenças altamente significativas a nível de ambientes, genótipos e interação genótipo-ambiente para ferro e zinco, demonstrando uma adaptabilidade diferencial dos genótipos nos ambientes de teste. Os genótipos 2 e 3 expressaram maior adaptabilidade e estabilidade para o teor de ferro nos grãos; enquanto o genótipo 1, registrou-o para o teor de zinco. Esses três genótipos superaram o controle comercial e, portanto, podem ser recomendados para o plantio ou serem usados como parentais no programa de melhoramento genético.

Palavras-chave: Vigna unguiculata. Biofortificação. Interação Genótipo-ambiente. Micronutrientes. Desnutrição.

\footnotetext{
${ }^{*}$ Corresponding author

${ }^{1}$ Received for publication in 05/08/2020; accepted in 05/27/2021.

${ }^{2}$ Department of Agronomic Engineering and Rural Development, Universidade de Cordoba, Montería, CO, Colombia; cecardona@correo.unicordoba.edu.co - ORCID: 0000-0002-9607-3858, aramendiz@correo.unicordoba.edu.co-ORCID: 0000-0002-2585 -6273,mmespitia@correo.unicordoba.edu.co - ORCID: 0000-0001-7382-9643.
} 


\section{INTRODUCTION}

Cowpea (Vigna unguiculata (L.) Walp), is cultivated in tropical and subtropical areas of the world and for the year 2018, 12.496.305 ha were harvested with a production of 7.233.408 $\mathrm{t}$ (FAO, 2020). It is consumed as green and dry grain, and as fodder, for its protein, iron and zinc contents (MÁRQUEZ-QUIROZ et al., 2015; GERRANO et al., 2019), since they contribute significantly to mitigate the problems of hidden hunger, in vulnerable populations in both rural and urban areas of the Colombian Caribbean.

Mineral deficiencies in the populations of northern Colombia are related to frequent consumption of cereals and tubers with poor iron content, which affects the level of hemoglobin, and the transport of oxygen in the blood, DNA synthesis, metabolic processes and energy production (LIU et al., 2014; SINGH et al., 2016). On the other hand, zinc deficiency affects bone formation, the immune system, increases the susceptibility to developing cancer, and affects sexual functionality and maturation (LIU et al., 2014; GADDAMEEDI et al., 2018).

An alternative to mitigate the public health problems caused by hidden hunger (KUMAR et al., 2019), is the biofortification of crops (GUILLÉNMOLINA et al., 2016), apart from other options such as crop fertilization, fortification of food products and vitamin and mineral supplementation (SINGHAL et al., 2018). Biofortification respects eating habits with economic and social advantages for people with lower incomes. For this reason, the genetic improvement of crops focuses on improving yield and nutritional quality to contribute to the improvement of the biochemical indicators of iron, zinc and other minerals.

Genotype-environment interaction affects quantitative characteristics such as the yield and the content of iron and zinc, as has been reported for mung beans (SINGH et al., 2013); cowpea (OLIVEIRA et al., 2017), lentil (DARAI et al., 2017); pearl millet (SINGHAL et al., 2018) and rice (INABANGAN-ASILO et al., 2019), becoming an obstacle to the plant breeder, in the identification and selection of stable genotypes for these two characteristics in the grain (DARAI et al., 2017).

Various methods have been used to measure the genotype-environment interaction for iron and zinc, including that of Eberhart and Russell (1966) by Singh et al. (2013), Kant's index by InabanganAsilo et al. (2019) and others. The AMMI method (Analysis of main additive effects and multiplicative interaction) has increasingly been applied in agricultural species (DARAI et al., 2017; OLIVEIRA et al., 2017; SINGHAL et al., 2018;
INABANGAN-ASILO et al., 2019), because it allows characterizing and grouping both genotypes and environments and analyzes genotypeenvironment interactions with greater efficiency (ZOBEL; WRIGHT; GAUCH, 1988) and its interpretation is facilitated by biplot charts. Therefore, the objective of this research was to evaluate the behavior of lines previously selected for high content of iron and zinc, in contrasting environments of the Colombian Caribbean to know their interaction by AMMI analysis and select the most stable genotypes for commercial planting or use as a parent.

\section{MATERIALS AND METHODS}

\section{Genetic material and experimental location}

Nine advanced lines of the genetic plant breeding program of the Universidad de Córdoba, Colombia, previously selected for their iron and zinc content, were used: 1 . LC-029-16; 2. LC-002-016; 3. LC-036-016; 4. LC-009-016; 5. LC-021-016; 6. L019; 7. LC-006-016; 8. LC-005-016; 9. L-014-016. and as a control 10. CAUPICOR. These lines were evaluated in 10 environments in the Caribbean region of Colombia in semesters second (B) of 2017 and first (A) of 2018, identified as follows: 1. Cereté -Córdoba (CE7B), 2. Mahates-Bolívar (MA7B), 3. Montería-Córdoba (MO7B), 4. Polonuevo-Atlántico (PN7B), 5. Sampués-Sucre (SA7B), 6. CeretéCórdoba (CE8A), 7. Leticia-Bolívar (LE8A), 8. Polonuevo-Atlántico (PN8A), 9. Sampués-Sucre (SA8A), and 10. Villanueva-Guajira (VI8A). Soils differ from one subregion to another, with fertility ranging from high to very low, depending on precipitation and the influence or not of rivers and tributaries. The experiments were carried out without edaphic fertilization or supplementary irrigation. The climate is tropical, a typical savanna subtype Aw, according to the Köppen classification, with a temperature variation between 24 and $28{ }^{\circ} \mathrm{C}$ and annual rainfall between 800 and $1800 \mathrm{~mm}$.

\section{Experimental design and statistical analysis}

In each environment the experimental design of complete random blocks with 10 treatments and four replications was used. The experimental unit consisted of plots of six rows of five meters long, spaced at $0.80 \mathrm{~m}$ and $0.40 \mathrm{~m}$ between plants for a population of 31.250 plants ha ${ }^{-1}$.

Determinations of the iron and zinc contents were made at the International Center for Tropical Agriculture (CIAT), Cali-Colombia. For this, 5 grams of seed were taken per treatment at harvest. 
The iron and zinc contents, in $\mathrm{mg} \mathrm{kg-}^{-1}$, was determined by atomic absorption spectroscopy using a Solaar Unicam 969 kit.

The analysis of variance for estimation of the main effects, and the effect of the genotypeenvironment interaction (GEI) explained by principal components was performed through the AMMI model (additive main effects and multiplicative interaction model). For this model, the effects of genotypes and environments are additive and linear, while GEI has multiplicative effects explained by principal component analysis (ZOBEL; WRIGHT; GAUCH, 1988; EBDON; GAUCH JR, 2002). The model is as follows:

$$
Y_{g e r}=\mu+\alpha_{g}+\beta_{e}+\sum_{n=1}^{N} \lambda_{n} \zeta_{g n} \eta_{e n}+\varepsilon_{g e r}
$$

The meaning of each model term is: $\mathrm{Y}_{\mathrm{ijk}}$ is the performance of genotype $g$ in environment e for repeat $r ; \mu$ is the general mean; $\alpha_{g}$ is the effect of genotype $g ; \beta_{e}$ is the effect of the environment $e$ and; $N$ is the number of axes in the principal component analysis (PCA) retained in the model; $\lambda_{n}$ is the eigenvalue for the $n$ axis of the PCA; $\varsigma_{g n}$ and $\eta_{e n}$ are the PCA scores for their own axes; and $\varepsilon_{g e r}$ is the model error.

PCA scores for environments and genotypes in the interaction have units equivalent to the square root of the response variable (EBDON; GAUCH JR, 2002). For the AMMI analysis the GEA-R software (Genotype $\mathrm{x}$ Environment Analysis with $\mathrm{R}$ for Windows) Version 4.1 of the International Center for Maize and Wheat Improvement CIMMYT (PACHECO et al., 2015) was used.

\section{RESULTS AND DISCUSSION}

Estimates of the mean squares of the main additive effects of environment (E), genotype $(\mathrm{G})$ and genotype-environment interaction (GEI) for the iron and zinc contents (Table 1) are highly significant $(p<0.01)$. This indicates that these minerals vary in genotypes according to the environment where they were cultivated, there is also variation between them and this variation is not independent, but each genotype accumulates in the grain different amounts according to the environment where it is cultivated, as has been evidenced in previous studies carried out by Muranaka et al. (2016), Oliveira et al. (2017), and Singhal et al. (2018). It is necessary to examine the GEI to know its magnitude and determine whether it is positive or negative in order to be successful in the selection and recommendation of cultivars for specific environments or multi-environments, given the importance of these micronutrients in human health, and to make a better use of the environmental supply (BASHIR et al., 2014; SINGHAL et al., 2018; SANTOS et al., 2019).

The sums of squares indicate that environments (E) retain $75.84 \%$ and $90.75 \%$, respectively, of the total variation of the AMMI model for both nutrients; secondly, the GEI with $18.50 \%$ and $6.97 \%$ and then, genotypes $(\mathrm{G})$, with $5.66 \%$ and $2.28 \%$, respectively, which is consistent with research on cowpea beans by Santos et al. (2015) and lentil by Darai et al. (2017).

The decomposition of the GEI into principal components and the Gollob test (1968) shows that, for iron content, the first two principal components (PC1 and PC2) were highly significant, the third (PC3) significant and together explain $77.22 \%$ of the sum of squares of the interaction with 45 of 81 degrees of freedom $(55.6 \%)$; the rest of the principal components are not significant, which in a first analysis constitutes the residual of the interaction. However, when the variation (sums of squares) includes components from the third (PC3) to the ninth (PC9) it is estimated as 1397.88 with 49 degrees of freedom, equivalent to a mean square of 28.53 that is not significant, with F-test value of 1.37 as can be deduced from Table 1 . This indicates that the first two principal components explain the GEI efficiently, since they represent $93.51 \%$ of the AMMI model, and the residual of the interaction is only $6.49 \%$.

For zinc content, despite the fact that the first two principal components were highly significant, the sums of squares from the second principal component to the ninth (PC2 to PC9) and the associated 64 degrees of freedom, allow the estimation of a CM of 8.24, which is not significant with an $\mathrm{F}$ value of 1.24. This indicates that, for the zinc content, the interaction is effectively explained with only the first principal component (PC1) that represents $95.86 \%$ of the AMMI model and the GEI residual only $4.14 \%$.

The biplot in which the abscissa shows the main effects (means of the genotypes and environments for the iron content) and ordered the first axis of the principal component analysis (PCA) of the AMMI model is presented in Figure 1. This graphical representation contains $81.50 \%$ of the sum of squares of the model and $42.74 \%$ of the sum of squares of the GEI and constitutes AMMI1, that is, the reduced model that includes only the first axis of the PCA. 
Table 1. Analysis of variance and Gollob's test of the AMMI Model for the iron and zinc contents of 10 cowpea genotypes (G) evaluated in ten environments (E) of the Colombian Caribbean 2017-2018.

\begin{tabular}{|c|c|c|c|c|c|c|c|c|c|c|c|}
\hline \multirow{2}{*}{ SV } & \multirow{2}{*}{ DF } & \multicolumn{4}{|c|}{ Iron } & \multirow[b]{2}{*}{ F } & \multicolumn{4}{|c|}{ Zinc } & \multirow[b]{2}{*}{ F } \\
\hline & & $\mathrm{SC}$ & $\% \mathrm{SS}$ & $\% \mathrm{SSA}$ & MS & & SS & $\% \mathrm{SS}$ & $\% \mathrm{SSA}$ & MS & \\
\hline $\mathrm{E}$ & 9 & 16344.2 & 75.8 & 75.8 & $1816.0^{* *}$ & 87.5 & 11567.2 & 90.8 & 90.8 & $1285.2 * *$ & 194.0 \\
\hline G & 9 & 1220.1 & 5.7 & 81.5 & $135.6^{* *}$ & 6.5 & 291.0 & 2.3 & 93.0 & $32.3 * *$ & 4.9 \\
\hline GEI & 81 & 3987.6 & 18.5 & 100.0 & $49.2 * *$ & 2.4 & 888.0 & 7.0 & 100.0 & $11.0 * *$ & 1.7 \\
\hline $\mathrm{PC} 1$ & 17 & 1704.1 & 42.7 & 42.7 & $100.2 * *$ & 4.9 & 360.4 & 40.6 & 40.6 & $21.2 * *$ & 3.3 \\
\hline PC2 & 15 & 885.6 & 22.2 & 64.9 & $59.0 * *$ & 2.9 & 241.3 & 27.2 & 67.8 & $16.1 * *$ & 2.5 \\
\hline PC3 & 13 & 489.3 & 12.3 & 77.2 & $37.6^{*}$ & 1.8 & 120.6 & 13.6 & 81.4 & $9.3 \mathrm{~ns}$ & 1.4 \\
\hline PC4 & 11 & 368.5 & 9.2 & 86.5 & $33.5 \mathrm{~ns}$ & 1.6 & 73.6 & 8.3 & 89.6 & $6.7 \mathrm{~ns}$ & 1.0 \\
\hline PC5 & 9 & 252.7 & 6.3 & 92.8 & $28.1 \mathrm{~ns}$ & 1.4 & 51.6 & 5.8 & 95.5 & $5.7 \mathrm{~ns}$ & 0.9 \\
\hline PC6 & 7 & 173.5 & 4.4 & 97.2 & $24.8 \mathrm{~ns}$ & 1.2 & 22.6 & 2.6 & 98.0 & $3.2 \mathrm{~ns}$ & 0.5 \\
\hline PC7 & 5 & 109.7 & 2.8 & 99.9 & $21.9 \mathrm{~ns}$ & 1.1 & 10.2 & 1.2 & 99.1 & $2.0 \mathrm{~ns}$ & 0.3 \\
\hline PC8 & 3 & 4.0 & 0.1 & 100.0 & $1.3 \mathrm{~ns}$ & 0.1 & 5.9 & 0.7 & 99.8 & $2.0 \mathrm{~ns}$ & 0.3 \\
\hline PC9 & 1 & 0.2 & 0.0 & 100.0 & $0.2 \mathrm{~ns}$ & 0.01 & 1.8 & 0.2 & 100.0 & $1.8 \mathrm{~ns}$ & 0.3 \\
\hline $\mathrm{PC} 10$ & & 0 & 0 & 100.0 & 0 & 0.00 & 0 & 0 & 100.0 & 0 & 0 \\
\hline Error & 300 & 6227.88 & 0 & 0 & 20.8 & & 1987.44 & 0 & 0 & 6.62 & \\
\hline
\end{tabular}

SV: source of variation; DF: degrees of freedom; SS: sums of squares; MS: mean squares; \% SS: percentage of the sum of squares; $\% \mathrm{SSA}=$ percentage of the sum of squares accumulated; $\mathrm{PC}_{1}, \mathrm{PC}_{2}, \ldots, \mathrm{PC}_{10}=$ principal component $1,2, \ldots, 10$, respectively; $* *=$ significant at $1 \%$; *: significant at $5 \%$; ns: not significant.

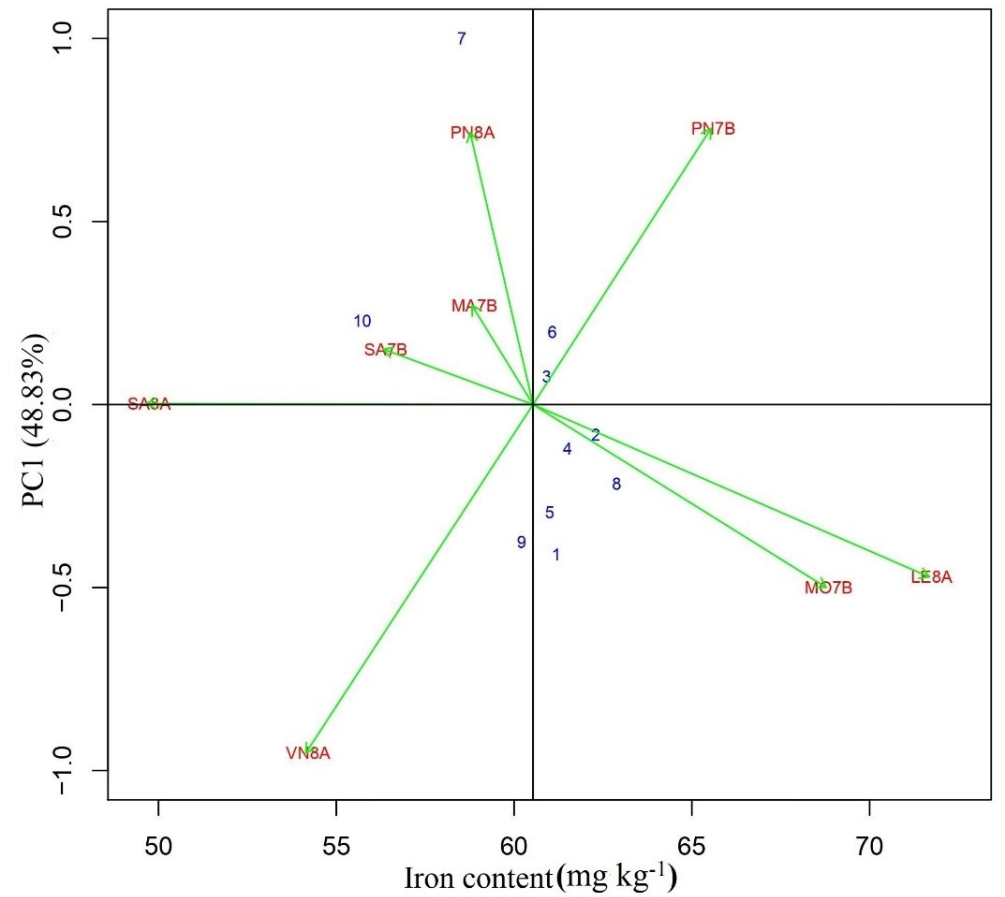

Figure 1. Biplot of the AMMI model for the iron content $\left(\mathrm{mg} \mathrm{kg}^{-1}\right)$ of 10 cowpea genotypes evaluated in 10 environments of the Colombian Caribbean. The codes of environments and genotypes are described in Materials and Methods. 
More favorable environments for iron contents and above the average were observed in Montería (MO7B), Leticia (LE8A) and Polonuevo (PN7B), while the most unfavorable were in Sampués (SA8A) and Villanueva (VI8A). In Sampués (SA7B), Mahates (MA7B), Polonuevo (PN8A) and Cereté (CE7B and CE7A), slightly lower than average contents were recorded (Table 2). On the other hand, genotypes $1,2,3,4,5$, and 8 had above-average iron content, while genotypes $6,7,9$ and 10 were below. It is important to note that environments considered unfavorable can be improved through management, especially with adjustments to fertilizers with these micronutrients.

The dispersion of the environments was higher than that of the genotypes and much more contrasting due to macroenvironmental and microenvironmental, biotic and abiotic factors. Likewise, it is highlighted that genotypes 2 and 3 with scores close to zero in PC1 are considered very stable with respect to the evaluated environments and their iron contents are above the average (Figure $1)$.

Genotypes 1, 2, 3, 4, 5, 8 and 9 interacted positively with five of the 10 environments: LE8A,
MO7B, VI8A, SA8A and CE7B, and negatively with the remaining five, while genotypes 6,7 and 10 interacted positively with the CE8A, MA7B, PN7B, PN8A, and SA7B environments, and negatively with the rest (Table 2). Positive interactions increase the estimated iron content with major effects and negative interactions decrease it. The Sampués environment score (SA8A) was the lowest, close to zero, so interaction with the 10 genotypes was also low, i.e. this environment does not significantly add or substract from the iron content of each genotype.

The Villanueva (VI8A) environment presented the highest positive score in the first axis of the PCA (Figure 1), with a strong influence on the positive interaction with genotypes $1,4,5,8$, and 9, and negative with genotypes 6 , and 10 , increasing and decreasing, respectively, the estimated iron content by adding the interaction effect to the main effects. In general, the environments with the lowest contribution to the GEI were Sampués (SA8A and SA7B), while the other environments contributed to a greater degree. Similar results, have been reported in pearl millet by Anuradha et al. (2017) and maize by Mallikarjuna et al. (2015).

Table 2. Iron content $\left(\mathrm{mg} \mathrm{kg}^{-1}\right)$ for 10 cowpea genotypes in 10 environments and means of the AMMI model with the first two principal components (PC1 and $\mathrm{PC} 2$ ) of the genotype-environment interaction analysis.

\begin{tabular}{|c|c|c|c|c|c|c|c|c|c|c|c|c|c|}
\hline \multirow{2}{*}{ Environment } & \multicolumn{10}{|c|}{ Genotype } & \multirow{2}{*}{ Mean } & \multirow{2}{*}{$\mathrm{PC} 1$} & \multirow{2}{*}{$\mathrm{PC} 2$} \\
\hline & 1 & 10 & 2 & 3 & 4 & 5 & 6 & 7 & 8 & 9 & & & \\
\hline CE7B & 55.0 & 57.3 & 56.0 & 62.4 & 62.6 & 59.3 & 53.1 & 49.7 & 62.4 & 58.5 & 57.6 & 0.55 & -0.62 \\
\hline CE8A & 61.6 & 58.4 & 58.5 & 57.1 & 59.0 & 61.0 & 53.4 & 63.9 & 61.2 & 57.1 & 59.1 & -0.54 & -0.45 \\
\hline LE8A & 74.2 & 69.5 & 71.3 & 69.9 & 73.4 & 73.7 & 68.8 & 66.2 & 72.9 & 77.7 & 71.8 & 0.48 & 0.10 \\
\hline MA7B & 58.5 & 55.4 & 61.6 & 59.0 & 57.4 & 57.9 & 64.3 & 58.0 & 57.8 & 59.1 & 58.9 & -0.29 & 0.64 \\
\hline MO7B & 70.0 & 58.1 & 67.8 & 69.2 & 71.7 & 72.4 & 72.5 & 62.7 & 72.6 & 71.5 & 68.9 & 0.55 & 0.68 \\
\hline PN7B & 63.3 & 61.6 & 63.9 & 65.2 & 65.8 & 64.8 & 69.4 & 71.5 & 65.8 & 64.9 & 65.6 & -0.82 & 0.43 \\
\hline PN8A & 58.2 & 53.9 & 61.2 & 63.2 & 60.0 & 56.3 & 56.5 & 65.0 & 59.5 & 54.6 & 58.8 & -0.80 & -0.32 \\
\hline SA7B & 58.0 & 54.6 & 57.8 & 55.2 & 55.0 & 57.1 & 60.1 & 54.4 & 59.0 & 52.9 & 56.4 & -0.18 & 0.31 \\
\hline SA8A & 46.6 & 46.1 & 56.3 & 49.8 & 53.4 & 49.5 & 45.1 & 47.3 & 57.4 & 45.8 & 49.7 & 0.05 & -0.84 \\
\hline VI8A & 60.8 & 46.7 & 58.6 & 55.9 & 55.5 & 56.3 & 51.9 & 43.1 & 58.2 & 55.3 & 54.2 & 1.00 & 0.06 \\
\hline Mean & 60.6 & 56.2 & 61.3 & 60.7 & 61.4 & 60.8 & 59.5 & 58.2 & 62.7 & 59.7 & 60.1 & & \\
\hline PC1 & 0.23 & -0.18 & 0.06 & 0.05 & 0.19 & 0.23 & -0.14 & -1.00 & 0.23 & 0.34 & & & \\
\hline PC2 & -0.13 & 0.08 & 0.48 & 0.17 & 0.20 & -0.13 & -0.66 & 0.00 & 0.39 & -0.42 & & & \\
\hline
\end{tabular}

The code of environments and genotypes are described in Materials and Methods.

The closer a genotype is to the origin of the ordinate, the less contribution it adds to the effect of the genotype-environment interaction, be it positive or negative, and presents greater stability in the iron content. The most stable genotypes differ from the rest in the efficiency of iron use and absorption. According to Figure 1, the genotypes that contributed the least to the effect of the interaction 
were 2 and 3 , although their iron contents were higher than the general average, so they could be recommended to farmers and genotype 7 showed greater interaction and consequently instability.

The AMMI2 biplot (Figure 2) has the first principal component (PC1) on the abscissa axis with $42.72 \%$ of the SS and the second principal component (PC2) on the ordinate axis with $22.21 \%$, both totaling $64.93 \%$ of the sum of squares of the GEI.

In Figure 2 it is corroborated that genotypes 2 and 3 are closer to the origin of the coordinates, so they can be considered as those with the highest buffering capacity or stability. On the other hand, the Sampués (SA7B) and Mahates (MA7B) environments contributed the most to the stability of the genotypes, although their iron accumulations were below average. The remaining eight environments, the furthest from the origin in the biplot and outside the polygon, contributed more to the GEI. In addition, genotypes $6,7,8,9$ and 10 , located at the vertices of the polygon, were the ones that responded most to environmental stimuli either positively or negatively, depending on the sign and magnitude of the scores.

In the orthogonal projections and closeness of the genotypes, and in the product of the PC1 scores for environments and genotypes, it was observed that genotypes $1,4,5,8$, and 9 interact positively and to a greater extent with environments VI8A, LE8A, MO7B and CE7B, while genotypes 6, 7 and 10 did so with PN7B, PN8A and CE8A, showing specific adaptability to these environments. The effect of the positive or negative interaction of genotypes 2 and 3 with all environments was almost zero, showing stability in the iron content.

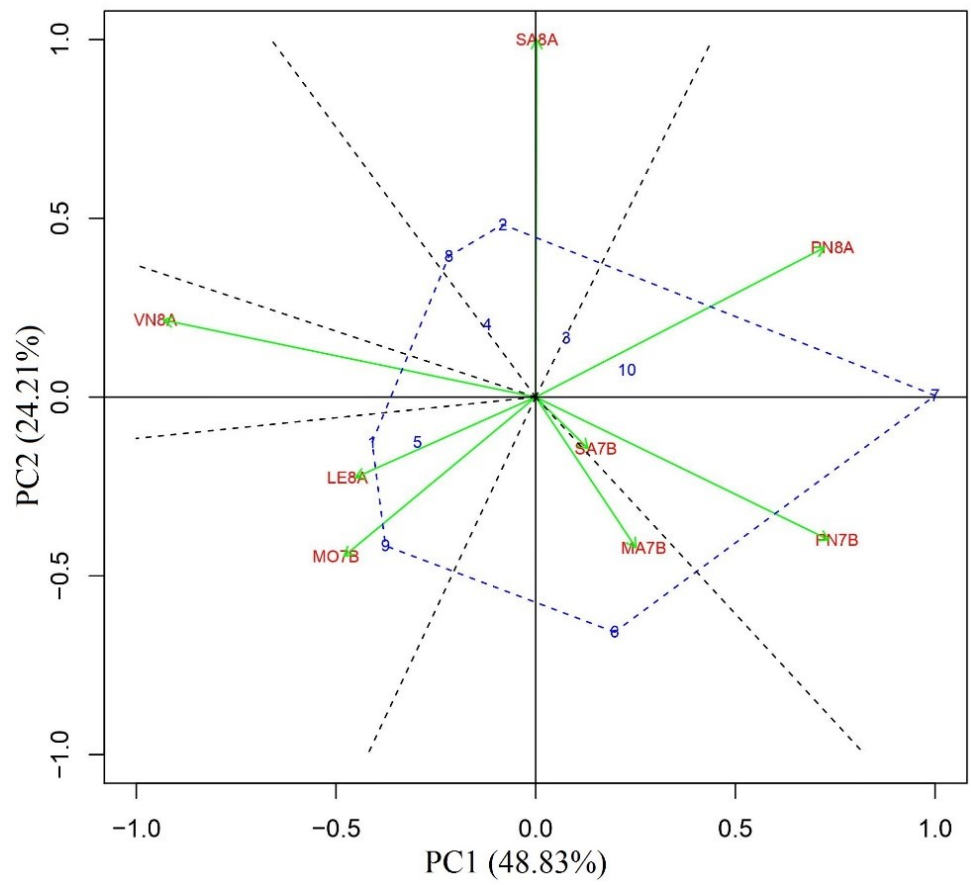

Figure 2. Biplot with the principal components PC1 and PC2 of the AMMI model for the iron content $\left(\mathrm{mg} \mathrm{kg}^{-1}\right)$ of 10 cowpea genotypes evaluated in 10 environments of the Colombian Caribbean. The codes of environments and genotypes are described in Materials and Methods.

The biplot for zinc content is presented in the Figure 3. This representation contains $93.03 \%$ of the sum of squares of the AMMI model and $40.59 \%$ of the sum of squares of the GEI and constitutes the AMMI1, that is, the reduced model in which the GEI is explained only with the first axis of the PCA, as explained above. Zinc contents above the average were observed in the MO7B, LE8A, CE7B, PN7B, MA7B, SA7B and PN8A environments; with MO7B having a great advantage with respect to the other environments (Table 3 ).

Lower than average zinc contents were observed in CE8A, VI8A, and SA8A. On the other hand, genotypes $1,2,3,4,6$ and 8 presented zinc contents above the average, and specific adaptability to SA7B, LE8A, MO7B, PN7B and MA7B environments. Genotype 6 stands out for its increased zinc contents and higher positive score in LE8A, MO7B and SA7B environments. The rest of the genotypes contents lower zinc contents (Table 3 ). Among the most stable due to their lower contribution to interaction, are genotypes 1, 5 and 9, with genotype 1 being the one with the best overall adaptability, as it shows greater accumulation of zinc (Figure 3).

Genotypes 2, 3, 4, 7 and 8 interacted positively and to a greater extent with the PN8A SA8A and VI8A environments, and negatively with 
the rest of the environments, while genotypes 6 and 10 interacted positively and with greater effect with the SA7B, LE8A and MO7B environments, as can be verified by multiplying the scores of the environments and genotypes in the first axis of the PCA.

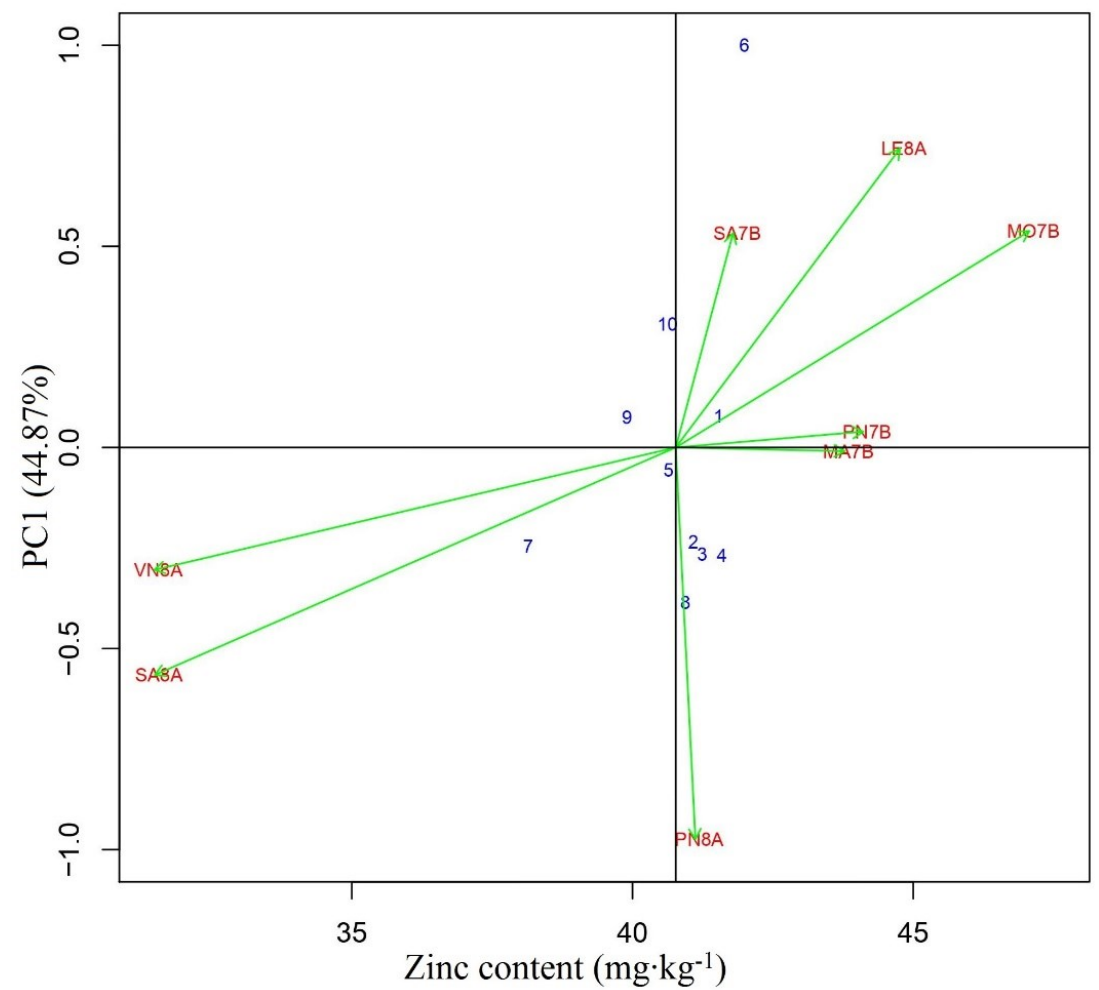

Figure 3. Biplot of the AMMI model for the zinc content $\left(\mathrm{mg} \mathrm{kg}^{-1}\right)$ of 10 cowpea genotypes evaluated in 10 environments of the Colombian Caribbean. The codes of environments and genotypes are described in Materials and Methods.

Table 3. Zinc content $\left(\mathrm{mg} \mathrm{kg}^{-1}\right)$ for 10 cowpea genotypes in 10 environments and means of the AMMI1 model with the first principal component (PC1) of the analysis of the genotype-environment interaction.

\begin{tabular}{|c|c|c|c|c|c|c|c|c|c|c|c|c|}
\hline \multirow{2}{*}{ Environment } & \multicolumn{10}{|c|}{ Genotype } & \multirow{2}{*}{ Mean } & \multirow{2}{*}{ PC1 } \\
\hline & 1 & 10 & 2 & 3 & 4 & 5 & 6 & 7 & 8 & 9 & & \\
\hline CE7B & 46.0 & 46.6 & 45.8 & 46.8 & 45.3 & 46.0 & 46.1 & 45.0 & 46.5 & 45.8 & 46.0 & 0.14 \\
\hline CE8A & 37.4 & 37.6 & 36.6 & 36.8 & 36.6 & 37.4 & 38.5 & 38.3 & 36.8 & 35.8 & 37.2 & -0.05 \\
\hline LE8A & 44.5 & 47.7 & 43.7 & 43.8 & 44.8 & 43.6 & 49.5 & 42.9 & 44.0 & 43.8 & 44.8 & -0.76 \\
\hline MA7B & 45.3 & 42.1 & 43.5 & 46.3 & 44.3 & 44.0 & 45.4 & 41.6 & 43.0 & 43.0 & 43.9 & 0.00 \\
\hline MO7B & 49.0 & 46.1 & 47.6 & 46.4 & 47.0 & 46.8 & 51.5 & 43.3 & 46.9 & 47.0 & 47.1 & -0.56 \\
\hline PN7B & 44.0 & 44.6 & 47.4 & 45.5 & 45.4 & 43.0 & 45.8 & 40.5 & 43.0 & 42.8 & 44.2 & -0.05 \\
\hline PN8A & 41.7 & 43.8 & 42.9 & 44.0 & 42.7 & 40.8 & 37.9 & 39.7 & 43.3 & 39.3 & 41.2 & 0.97 \\
\hline SA7B & 43.5 & 41.9 & 39.9 & 42.3 & 42.1 & 42.7 & 45.8 & 38.2 & 41.6 & 40.6 & 41.9 & -0.55 \\
\hline SA8A & 30.9 & 29.5 & 29.5 & 31.6 & 34.8 & 31.8 & 31.2 & 31.7 & 34.7 & 29.8 & 31.6 & 0.55 \\
\hline VN8A & 33.4 & 33.5 & 34.2 & 30.1 & 31.7 & 32.5 & 28.9 & 27.3 & 31.1 & 33.0 & 31.6 & 0.31 \\
\hline Mean & 41.6 & 40.9 & 41.1 & 41.4 & 41.5 & 40.9 & 42.1 & 38.9 & 41.1 & 40.1 & 40.9 & \\
\hline $\mathrm{PC} 1$ & -0.08 & -0.29 & 0.23 & 0.27 & 0.25 & 0.06 & -1.00 & 0.24 & 0.38 & -0.06 & & \\
\hline
\end{tabular}

The code of environments and genotypes aredescribed in Materials and Methods. 


\section{CONCLUSIONS}

The cowpea genotypes responsed differentially for the contents of iron and zinc in the grain, under the environmental condition of the Colombian Caribbean.

Cowpea genotypes 2 and 3 expressed greater stability and adaptability for iron contents, while genotype 1 demonstrated this for zinc; therefore, they can be cultivated in all the evaluated environments.

\section{ACKNOWLEDGEMENTS}

The authors express their thanks to Colciencias, Universidad de Córdoba and Fundación Promotora del Canal del Dique, for funding the research project on cowpea breeding.

\section{REFERENCES}

ANURADHA, N. et al. Evaluation of pearl millet [Pennisetum glaucum (L.) R. Br.] for grain iron and zinc content in different agro climatic zones of India. Indian Journal of Genetics and Plant Breeding, 77: 65-73, 2017.

BASHIR, E.M.A. et al. Patterns of pearl millet genotype-by-environment interaction for yield performance and grain iron (Fe) and zinc ( $\mathrm{Zn}$ ) concentrations in Sudan. Field Crops Research, 166: 82-91, 2014.

DARAI, R. et al. AMMI biplot analysis for genotype environment interaction on yield trait of high $\mathrm{Fe}$ content lentil genotypes in Terai and Mid-Hill environment of Nepal. Annals of Agricultural and Crop Sciences, 2: e-1026, 2017.

EBDON, J.S.; GAUCH JR, H .G. Additive Main and Multiplicative Interaction Analysis of National Turfgrass Performance Trials: I. Interpretation of Genotype x Envirinment interaction. Crop Science, 42: 489-496, 2002.

EBERHART, S.A.; RUSSELL, W.A. Stability parameters for comparing varieties. Crop Science, 6: 36-40, 1966.

FAO. 2020. Estadísticas de cultivo. Disponível em: http://www.fao.org/faostat/es/\#data/QC. Acesso em: 18 ago. 2020.

GADDAMEEDI, A. et al. Inheritance studies on grain iron and zinc concentration and agronomic traits in sorghum [Sorghum bicolor (L.) Moench].
Journal of Cereal Science, 83: 252-258, 2018.

GERRANO, A.S. et al. Selection of cowpea genotypes based on grain mineral and total protein content.Acta Agriculturae Scandinavica, 69: 155$166,2019$.

GOLLOB, H.F. A statistical model which combines features of factor analytic and analysis of variance techniques. Psychometrika, 33: 73-115, 1968.

GUILLÉN-MOLINA, M. et al. Biofortificación de frijol caupí (Vigna unguiculata L. Walp) con hierro y zinc. Revista Mexicana de ciencias Agrícolas, 9:3427-3438, 2016.

INABANGAN-ASILO, M. et al. Stability and G $\times$ E analysis of zinc-biofortified rice genotypes evaluated in diverse environments. Euphytica, 215:1-17, 2019.

KUMAR, S. et al. Crop biofortification for iron (Fe), zinc (Zn) and vitamin A with transgenic approaches. Heliyon,5: e01914, 2019.

LIU, H. et al. Grain iron and zinc concentrations of wheat and their relationships to yield in major wheat production areas in China. Field Crops Research, 156: 151-160, 2014

MALLIKARJUNA, M.G. et al. Stability performance of inductively coupled plasma mass spectrometry-phenotyped kernel minerals concentration and grain yield in maize in different agro-climatic zones. PLoS One, 10: e0140947, 2015.

MÁRQUEZ-QUIROZ, C. et al. Biofortification of cowpea beans with iron: iron's influence on mineral content and yield. Journal of Soil Science and Plant Nutrition, 15: 839-847, 2015.

MURANAKA, S. et al. Genetic diversity of physical, nutritional and functional properties of cowpea grain and relationships among the traits. Plant Genetic Resources, 14: 67-76, 2016.

OLIVEIRA, D.S. et al. Adaptability and tability of the zinc density in cowpea genotypes through GGEBiplot method. Revista Ciência Agronômica, 48: 783-791, 2017.

PACHECO, A. et al. 2015. "GEA-R (Genotype $\mathbf{x}$ Environment Analysis with $R$ for Windows) Version 4.1", https://hdl.handle.net/11529/10203, CIMMYT Research Data \& Software Repository Network, V16. Disponível em: https:// data.cimmyt.org/dataset.xhtml? persistentId=hdl:11529/10203. Acesso em: 19 abr. 2020 . 
SANTOS, A. et al. Nonlinear regression and multivariate analysis used to study the phenotypic stability of Cowpea Genotypes. Hortscience, 54: 1682-1685, 2019.

SANTOS, A. et al. Adaptability and stability of cowpea genotypes to Brazilian Midwest. African Journal of Agricultural Research, 10: 3901-3908, 2015.

SINGH, P. et al. Bioavailability of Fe and $\mathrm{Zn}$ in selected legumes, cereals, meat and milk products consumed in Fiji. Food chemistry, 207: 125-131, 2016.

SINGH, V. et al. Stability analysis in mung vean (Vigna radiata (L.) Wilczek) for nutritional quality and seed yield. Legume Research, 36: 56-61, 2013.

SINGHAL, T. et al. Genotype $\times$ environment interaction and genetic association of grain iron and zinc content with other agronomic traits in RIL population of pearl millet. Crop \& Pasture Science, 69: 1092-1102, 2018.

ZOBEL, R.; WRIGHT, M.; GAUCH, H. Statistical analysis of a yield trial. Agronomy Journal, 80: 388 $-393,1988$. 